\title{
Installation of Test Setup and Measurement Procedures in Fir Wood Hydraulic Conductance Measurement
}

\section{Instaliranje opreme i mjernih postupaka pri određivanju hidrauličke vodljivosti jelovine}

\author{
Original scientific paper • Izvorni znanstveni rad \\ Received-prispjelo: 10. 9. 2019. \\ Accepted-prihvaćeno: 14. 1. 2021. \\ UDK: $630 * 812.221$ \\ https://doi.org/10.5552/drvind.2021.1945
}
(C) 2021 by the author(s). Licensee Faculty of Forestry and Wood Technology, University of Zagreb. This article is an open access article distributed under the terms and conditions of the Creative Commons Attribution (CC BY) license.

\begin{abstract}
For a hydraulic conductor, through which liquid flows, hydraulic conductance $\left(K, \mathrm{ml} \cdot \mathrm{s}^{-1} \cdot \mathrm{MPa}^{-1}\right)$ is defined as the ratio of pressure difference at the inlet and outlet to the fluid amount passing through the hydraulic conductor in a unit time period. This property is one of the key functions of the wood, and is obtained by the flow rate $\left(F-F l o w, ~ m l \cdot s^{-1}\right)$ along the wood sample divided by the pressure difference driving the flow $(\triangle P, M P a)$. This study aimed to establish a test setup to determine the hydraulic conductance values of Uluda $\breve{g}$ Fir (Abies bornmulleriana Mattf.). A test setup was established to measure the amount of water that flows in samples and pressure difference in characterized capillary tubes. In addition, calibration of the test apparatus is explained in detail. Fir wood samples taken from Yedigoller, which is affiliated to Kale Operation Chieftainship and Bolu Forest Regional Directorate, of $4 \mathrm{~mm}$ in diameter and $3 \mathrm{~cm}$ in length were prepared and hydraulic conductance measurements were performed, and the results are presented in this article. The installed test setup was used to obtain the following information about trees: operation of the hydraulic conduction system, the amount of needed water, seasonal effects and stress-related changes.
\end{abstract}

Keywords: hydraulic conductance; test setup; fir wood

\begin{abstract}
SAŽETAK • Hidraulička vodljivost $\left(\mathrm{K}, \mathrm{ml} \cdot \mathrm{s}^{-1} \cdot \mathrm{MPa}^{-1}\right)$ definira se kao omjer količine tekućine koja prolazi u određenom vremenu hidrauličkim vodičem i razlike tlaka na ulazu i izlazu vodiča. To je svojstvo jedna od ključnih funkcija drva, a njegova se veličina određuje mjerenjem brzine protoka (F-protok, $\left.\mathrm{ml} \cdot \mathrm{s}^{-1}\right)$ uzduž uzorka drva zbog razlika tlakova $(\triangle P, M P a)$. Cilj ovog istraživanja bio je instaliranje mjernog sustava za određivanje hidrauličke vodljivosti jelovine (Abies bornmulleriana Mattf.). Postavkama mjerenja utvrđena je količina vode koja teče u uzorcima jelovine i razlika tlaka u karakterističnim kapilarama. Usto je detaljno objašnjeno kalibriranje ispitne opreme. Uzorci jelovine na kojima su provedena mjerenja hidrauličke vodljivosti bili su promjera $4 \mathrm{~mm}$ i duljine 3 cm i uzeti su s područja Yedigoller, a rezultati ispitivanja prikazani su u ovom radu. Instaliranim mjernim sustavom dobivene su ove informacije o stablima: djelovanje sustava hidrauličke vodljivosti u drvu, količina potrebne vode, utjecaji godišnjih doba i promjene povezane sa stresom.
\end{abstract}

Ključne riječi: hidraulička vodljivost; mjerni sustav; jelovina

\footnotetext{
Bolu Abant Izzet Baysal University, Mudurnu Sureyya Astarci Vocational School, Mudurnu, Bolu, Turkey.

${ }^{2}$ Bartın University, Faculty of Forestry, Department of Forest Industry Engineering, Bartin, Turkey.

${ }^{3}$ Nigde Omer Halisdemir University, Faculty of Engineering, Department of Mechanical Engineering, Nigde, Turkey.
} 


\section{INTRODUCTION}

\section{UVOD}

The transportation of water in trees is provided by the conduit network that runs along the soil, roots, stem and leaves. This operation is regulated by hydraulic conductance. Hydraulic conductivity of a whole tree is directly related to the length and permeability of the conduit network (Hubbard et al., 1999). Therefore, determining the hydraulic conductance in trees is important for understanding the absorption and transportation of water (Torres-Ruiz et al., 2012). Hydraulic conductance can also be used to comparatively measure the general hydraulic adaptation between species and to assess the impact of environmental change, particularly drought, on transportation of water (Cochard et al., 1996; Davis et al., 1999; Ladjal et al., 2005; Melcher et al., 2012; Sperry and Love, 2015; Fontes et al., 2018).

It is suggested that the water transportation in trees, provided by the pipes from the roots to the leaves, may be similar to the flow provided by the circular and smooth-walled capillary pipes (Tyree and Zimmermann, 2002). Hagen-Poiseuille law was used based on this assumption. Hagen and Poiseuille proposed an equation to describe the flow velocity and rate of fluid flow through a circular tube $\left(k=\pi \cdot r^{4} / 8 \cdot \eta\right)$. Accordingly, the hydraulic conductance, $k$, is related to the fourth power of the total diameter of the transmission pipes (Tyree and Ewers, 1991). However, since the internal anatomy and interconnections of xylem channels are more complex than a series of parallel flat-walled tubes and small errors in diameter measurement increase by the fourth power, the calculated xylem hydraulic conductance values typically exceed the measured conductance (Tyree and Ewers, 1991; Tyree and Zimmermann, 2002; Sperry et al., 2005). Gibson et. al. (1984) state that the hydraulic conductivity values calculated using the tracheid diameters and Hagen Poiseuille equation are generally twice the measured conductance.

Hydraulic conductance measurements are commonly performed on chopped wood samples with measuring devices installed in the laboratory environment. Wood samples are connected to a hydraulic system to measure the pressure difference $(\Delta P)$ and mass flow rate $(F)$ of a liquid (usually water) throughout the sample. Hydraulic conductance $\left(K ; \mathrm{kg} \cdot \mathrm{s}^{-1} \cdot \mathrm{MPa}^{-1}\right)$ is calculated with the $F / \Delta P$ ratio in its simplest form. In addition, the hydraulic conductivity $\left(K_{h} ; \mathrm{kg} \cdot \mathrm{s}^{-1} \cdot \mathrm{MPa}^{-1} \cdot \mathrm{m}\right)$ is the ratio between water flux $\left(F, \mathrm{~kg} \cdot \mathrm{s}^{-1}\right)$ through an excised sample segment and the pressure gradient $(\Delta P$ $/ \Delta x, \mathrm{MPa}^{-1} \cdot \mathrm{m}^{-1}$ ) causing the flow (Cruiziat at al., 2002). The specific conductivity $\left(K, \mathrm{~kg} \cdot \mathrm{s}^{-1}\right.$. $\mathrm{m}^{-1} \cdot \mathrm{MPa}^{-1}$ ) (hydraulic conductivity per sapwood area, $\left.K_{h} / S\right)$ is obtained by dividing a unit pressure potential gradient $\left(\mathrm{MPa}^{-1} \cdot \mathrm{m}^{-1}\right)$ per sapwood cross-sectional area by the flow rate $\left(F, \mathrm{~kg} \cdot \mathrm{s}^{-1}\right)$ generated by a branch or stem (Granier et. al., 1989; Pallardy, 2008).

One of the techniques used to measure the hydraulic conductance in the laboratory was introduced by Sperry et al. (1988). In the assembled setup, a pres- sure difference between 3-10 kPa was created between the inlet and outlet points of the cut root and stem parts to provide the flow of solution. The flow rate was found by measuring the outgoing solution mass per second by a digital balance connected to the end of the wood sample. A similar device (HPFM - High Pressure Flow meter) has likewise been used to make comparative measurements of fluid conduction in roots and shoots, benefiting from the relationship between pressure change and hydraulic conductance (Tyree et al., 1995). A different way of determining the flow rate, which is one of the main parameters in measuring hydraulic conductance, is proposed by Melcher et al. (2012). Also, Cochard (2002) disclosed a method for measuring the hydraulic conductivity of cut xylem fragments exposed to high negative pressures. In this method, a centrifugal force is used for creating a negative pressure $(P)$ on the sample and to create a positive hydrostatic pressure difference $(\Delta P)$ between the two ends of the sample. The pressure difference $(\Delta P)$ allows the water to pass through the sample at a flow rate $(F)$ optically determined during centrifugation. The sample hydraulic conductance $(k)$ is obtained from $(\Delta P)$ and $F$.

In addition to conductance measurements along cut wood samples, measurements can be made along the whole shoot or root. Kolb et al. (1996) used a vacuum tube connected to a vacuum pump to create a pressure difference in the apparatus which was set up for this purpose. While the vacuum tube applies vacuum throughout the entire shoot, the stem base of the shoot is in a solution on the balance. Tyree et al. (2002) used a similar method (ULFM - Ultra Low Flowmeter) to measure hydraulic conductance along the entire stem. Hydraulic conductance of an individual vessel can also be measured, different from the measurements involving a certain length of cut wood samples and the entire stem-shoot-root system (Christman and Sperry, 2010; Zwieniecki et al., 2001).

This study, which aims to explain the installation of the test setup, operation of the system and measurement steps in order to measure the hydraulic conductance on fir wood samples, is a pioneering work for further studies. The purpose of this study is to contribute to the understanding of issues about how trees transport water and adapt to environmental and seasonal conditions which have aroused curiosity from past to present.

\section{MATERIALS AND METHODS}

\section{MATERIJALI I METODE}

\subsection{Material}

2.1. Materijal

The research sample of Uludağ Fir (Abies bornmulleriana Mattf.) was supplied from Yedigoller, which is affiliated to Kale Operation Chieftainship and Bolu Forest Regional Directorate. The fir tree taken from the region at an altitude of $1236 \mathrm{~m}$ is 75 years old and has $30 \mathrm{~cm}$ in diameter and $25 \mathrm{~m}$ in height. Samples were prepared by cutting $15 \mathrm{~cm}$ thick pieces like a wheel from the stem, which were taken from a height 
of $1.3 \mathrm{~m}$. In order to carry out the measurements, longitudinal segments were removed to cover the 7-13th annual rings after cambium. Then, the pieces were turned into thin beads, which were rounded to a diameter of $4 \mathrm{~mm}$. They were cut to $3 \mathrm{~cm}$ in length. Prepared samples were immersed in phenol dripped water until the measurement.

To find hydraulic conductance, distilled water at room temperature $\left(25^{\circ} \mathrm{C}\right)$ is used as the liquid in the system. Capillary tubes are characterized with water. All tests are performed with the same liquid and therefore test results can be compared. Another type of liquid can also be used in the system; in this condition all calibration and characterization processes should be performed on this liquid.

\subsection{Method}

2.2. Metoda

The measurement of the hydraulic conductance is based on the pressure difference between the inlet and outlet points of the samples. In this study, in order to determine the hydraulic conductance of the fir wood in the longitudinal direction, a test setup was established by examining this principle and reviewing the devices established for similar tests in the literature (Pereira and Mazzafera, 2012; Tyree et al., 2002).

\subsubsection{Installation of test assembly}

\subsubsection{Instalacija ispitnog sklopa}

The test apparatus for measuring the hydraulic conductance of the wood particles are shown in Figure 1.

In this apparatus:

- 3-way valves were used for routing the pressurized fluid in the system,

- capillary tubes that have 3 different inner diameters and lengths were used to determine different flow rates and to provide comparative data,

- a calibration tube was used to find the pressure difference caused by the internal resistance of the system and to remove the air gaps in the wood samples, - pressure sensors were used to measure the inlet (Pressure Sensor 1) and outlet pressures (Pressure

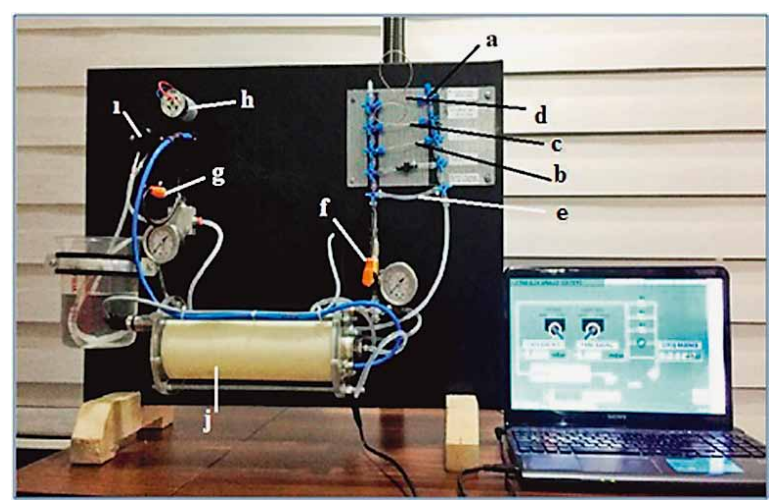

Figure 1 Hydraulic conductance test setup: a) Three-way valve, b) Capillary tube 1, c) Capillary tube 2, d) Capillary tube 3, e) Calibration tube, f) Pressure sensor 1, g) Pressure sensor 2, h) Vacuum pump, i) Peristaltic liquid pump, j) Vacuum tube

Slika 1. Sustav za mjerenje hidrauličke vodljivosti: a) trosmjerni ventil, b) kapilara 1, c) kapilara 2, d) kapilara 3, e) kalibracijska cijev, f) senzor tlaka 1, g) senzor tlaka 2, h) vakuumska pumpa, i) peristaltička pumpa, j) vakuumska cijev

Sensor 2) as well as the vacuum pressure (Pressure Sensor 3) in the vacuum tube,

- a vacuum pump was used to apply the vacuum in a vacuum tube used to place the sample,

- a peristaltic liquid pump was used to pressurize the liquid that supplied it to the system,

- a measuring cylinder was also used to collect and measure the amount of liquid passing through the pipes.

Also, in order to record the data and control test setup via computer, controller (Siemens-Step $7 \mathrm{CPU}$ 315), controller software (Siemens-Step 7 Version 5.5) (Figure 2) and data acquisition system (WinCC Flexible) were installed.

While operating the system, whose schematic view is given in Figure 3a, firstly the properties of the system elements are determined. When the test sample is not connected to the system, the pressurized liquid is passed through capillary tubes to measure the pressure

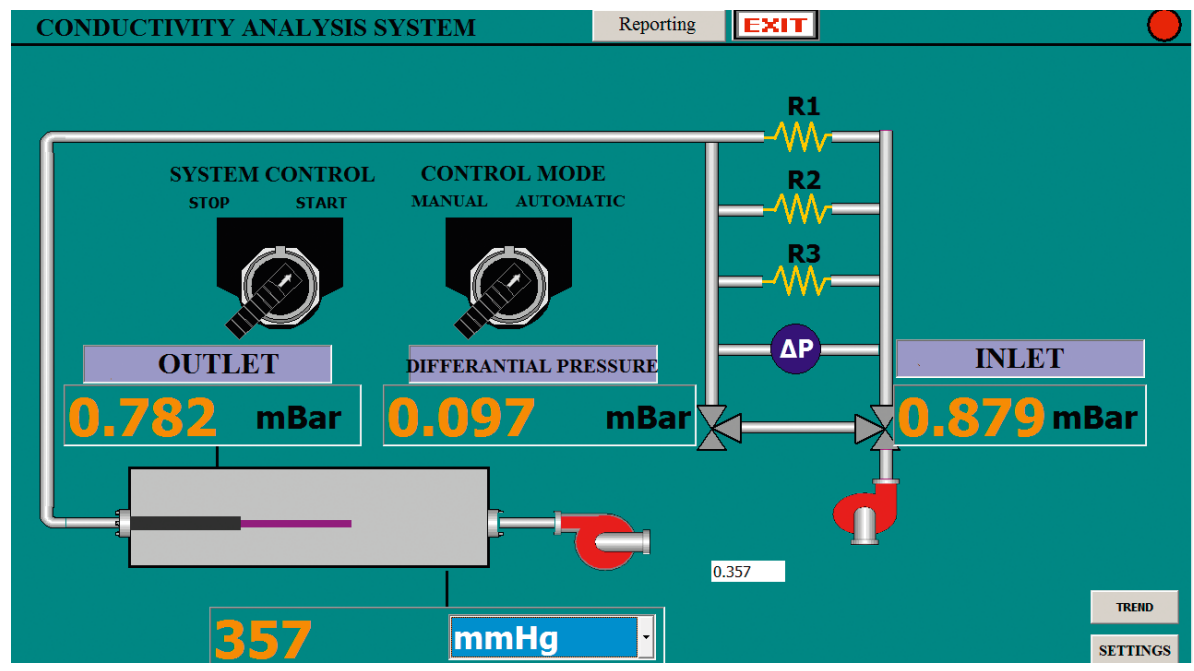

Figure 2 Controller software interface

Slika 2. Sučelje upravljačkog softvera 
change and flow rate, thus obtaining the pressure-flow relationship of each capillary tube. The pressurized liquid is applied to the system and liquid flows in scale vessel after passing through the selected capillary tube in a given time period. The pressure difference is measured by the difference between inlet and outlet pressures and the flow rate is determined by water amount at a defined time period. Different pressures are applied to each capillary tube to obtain the pressure-flow characteristics of the tubes. Then, the wood sample in the vacuum tube is connected to the end and pressurized liquid is applied to the system. Then the pressure difference in the capillary tube is measured and after that the amount of liquid passing at a given time is determined by using the previously determined pressureflow relationship. The measured liquid amount also refers to the amount of liquid passing through the wood sample. Liquid pressure applied to the wood sample that is also the outlet pressure of capillary tubes and the pressure in the vacuum tube is measured, and then the pressure difference on the sample is determined from the difference of these two values. The ratio of the amount of fluid passing at a given time and the pressure difference $(F / \Delta P)$ gives the hydraulic conductance of the wood sample.

\subsubsection{Test setup measurement calibration}

\subsubsection{Kalibriranje mjernog sustava}

The aim of the system calibration is to adjust the pressure difference when the calibration tube, which has a much greater inner diameter than capillary tubes and ignorable resistance, is used in the system. In other words, the aim of calibration is to find the pressure difference due to the inner resistance of system piping and sensor reading error. Test measuring was calculated with respect to the obtained pressure difference data.

When performing system calibration, the valve position is adjusted so that the fluid passes through the calibration tube. A wood sample is connected to the end of the system in order to create pressure. At this stage, the Vacuum Pump and Pressure Sensor 3 are not used (Figure 3b). The pressure is applied to the system during calibration. After the system pipes are filled with liquid and the system is stabilized, the measurement is made by Pressure Sensor 1 and Pressure Sensor 2. The difference in the measured values is recorded by the data acquisition system.

\subsubsection{Capillary tube characterization}

\subsubsection{Karakterizacija kapilare}

In capillary tube characterization, the aim is to determine the pressure-flow relationship characteristics of each capillary tube. Three different capillary tubes were used in the test setup. Capillary Tube 1 has an internal diameter of $0.17 \mathrm{~mm}$ and a length of $9.5 \mathrm{~cm}$, Capillary Tube 2 has an internal diameter of $0.17 \mathrm{~mm}$ and a length of $28 \mathrm{~cm}$, Capillary Tube 3 has an internal diameter of $0.13 \mathrm{~mm}$ and a length of $28 \mathrm{~cm}$. Three capillary tubes, as the combination of same diameter, different length, and same length, different diameter, were used to get reliable and comparable results. The graphs are obtained as a result of the characterization process that is applied separately for all three capillary tubes and, are used to measure the fluid conduction of the wood samples. Different pressures in the range of $50-100 \mathrm{kPa}$ (0.50-1 bar) are applied to the system for each capillary tube to measure the amount of liquid flowing. For each pressure value, there is a flow rate value, and using all measures a trend curve equation can be obtained. With the help of this equation, the measured pressure difference value can be used to find the flow rate.

In capillary tube characterization, the outlet of the system is open to the external environment. A scale vessel is placed to measure the amount of fluid flowing to the outlet. While closing the calibration pipe valve, the valve is set to the position in order to allow fluid to pass only through the pipe to be characterized (Figure 3c). Vacuum Pump and Pressure Sensor 3 were not used for this operation.

During the process, the system is first pressurized and then the system has to be filled with liquid. When the system reaches its balance and liquid is seen at the system outlet, time measurement is started. When a certain amount of fluid is collected in the scale vessel, the system is switched off and the amount of fluid collected in the scale vessel and the elapsed time is recorded. The values of pressure difference are recorded during this time by the data acquisition system. Then, the same process is continued with increasing applied pressure. After different pressures in the range of 95$100 \mathrm{kPa}(0.95-1 \mathrm{bar})$ are applied, the process is terminated and the results are evaluated.

$$
\frac{F}{\Delta P}=\frac{\text { Water amount in scaled vessel in given time }\left(\frac{\mathrm{ml}}{\mathrm{s}}\right)}{\text { Applied Pressure }- \text { Outlet Pressure }}
$$

\subsubsection{Measurement of hydraulic conductance} 2.2.4. Mjerenje hidrauličke vodljivosti

\section{Preliminary process}

In order to measure the hydraulic conductance of wood samples, pressurized water should be applied to the samples as a preliminary process. The purpose of this process is to remove air and small sediments, which may affect the fluid flow within the sample. While applying pressurized water, the valve positions are adjusted to let the liquid only pass through the selected calibration tube. The sample is connected to the end of the system and the system is pressurized. After waiting for the sample to get completely wet, the system is turned off. This process is applied to each sample to be measured just before the test.

\section{Measurement Procedure}

After the preliminary process is applied to wood samples, the hydraulic conductance values for each sample are measured using the calibrated system. Before starting the measurement process, the wood sample that has been subjected to pressurized water is placed in the vacuum tube and the calibration pipe valve is closed.

During the measurement:

1. The valve is positioned to allow the flow of liquid only through Capillary Tube 1; 


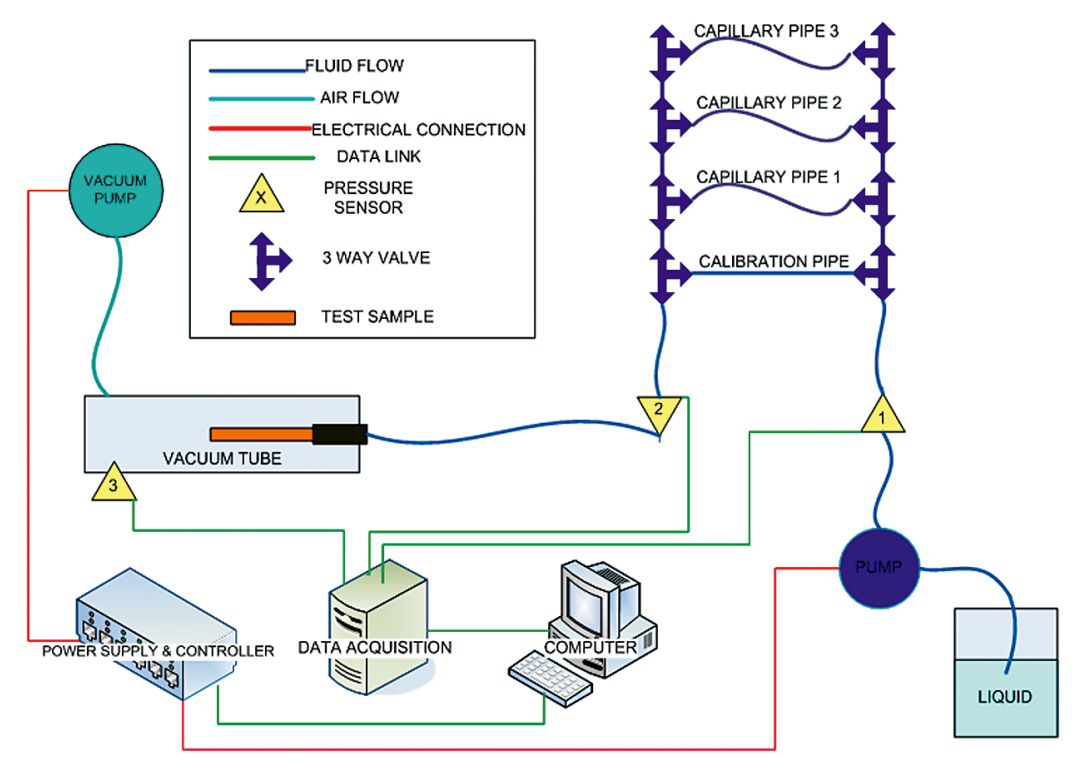

(a)

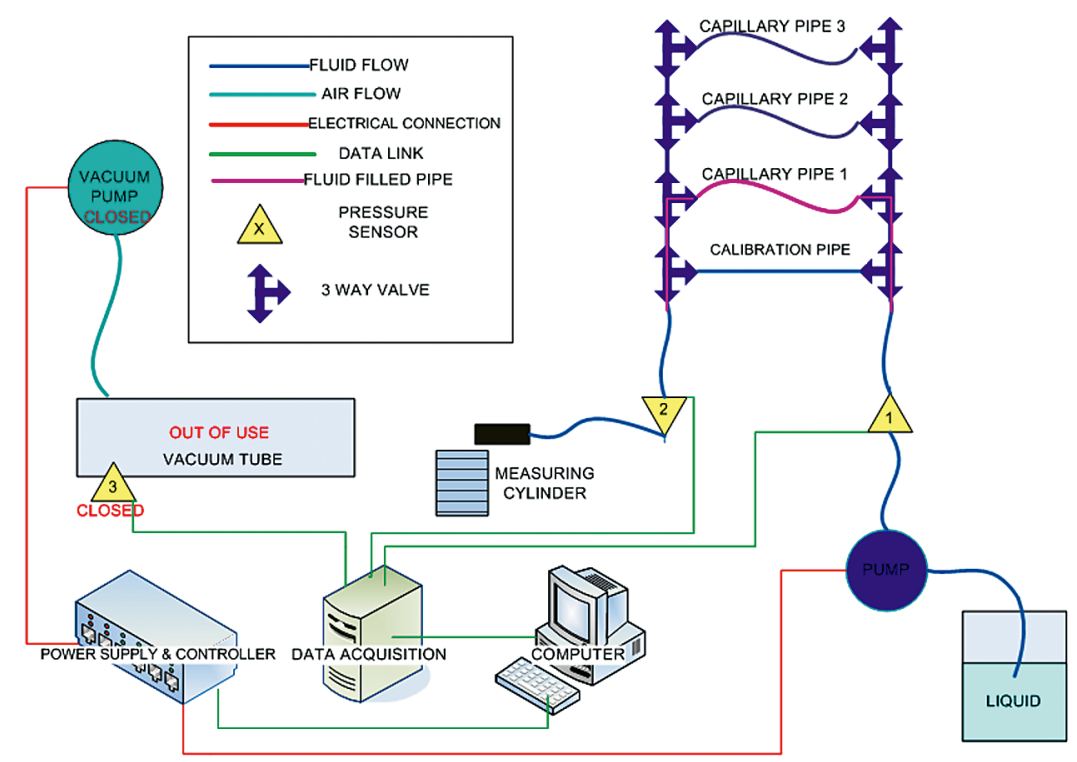

(b)

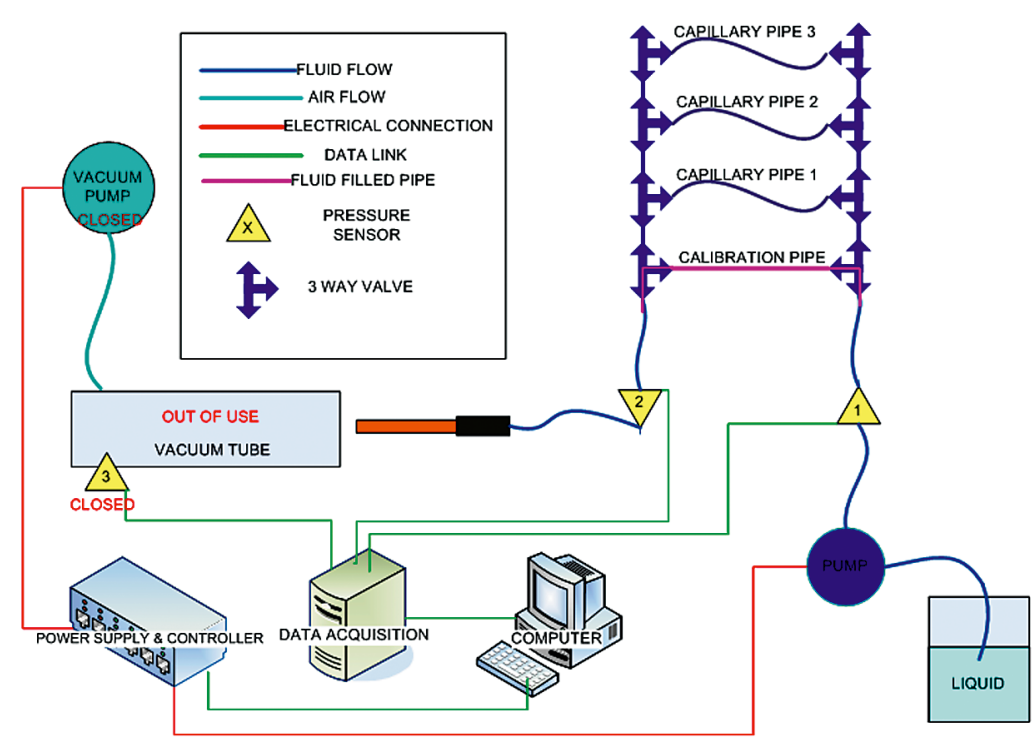

(c)

Figure 3 a) Schematic view of hydraulic conductance setup, b) System calibration, c) Capillary tube characterization Slika 3. a) Shematski prikaz sustava za mjerenje hidrauličke vodljivosti, b) kalibriranje sustava, c) karakterizacija kapilare 


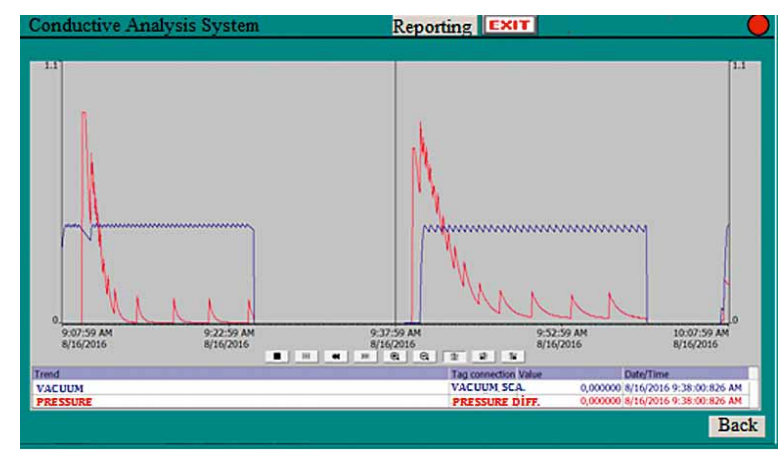

Figure 4 Trend curves showing that the system has reached saturation

Slika 4. Krivulje trenda pokazuju zasićenost sustava

2. The vacuum pump and pump pressure are set;

3 . The system is started to operate by the control software;

4. Pressure Sensor 2 values are monitored until giving stable results;

5. The Trend Curve is controlled by the Control Software to determine the time interval for measurement that the system has reached saturation and fluid delivery is smooth and sufficient (Figure 4). Measurement time is about 10 minutes;

6. The system is turned off;

7. The pressure difference value received by the Data Acquisition System, the Pressure Sensor 1 (Output pressure) value and the Pressure Sensor 3 (Vacuum pressure) value are recorded as the average of the values taken over the time interval specified in step 5;

8. Steps 2-7 are repeated after positioning the valve position, which allows the liquid only to pass through the Capillary Tube 2;

9. Steps $2-7$ are repeated after positioning the valve position which allows liquid only to pass through the Capillary Tube 3;

10. Fluid conduction quantities are determined by using pressure difference values from curves obtained after capillary tube calibrations;

11. The results are evaluated, and the flow rate of the sample at a given time is determined;

12. Pressure difference part of the sample is determined by using the values of Pressure Sensor 2 and Pressure Sensor 3;

13. Hydraulic conductance is calculated by proportioning the flow rate and pressure difference.

\section{RESULTS AND DISCUSSION}

\section{REZULTATI I RASPRAVA}

\subsection{Test setup findings}

3.1. Nalazi mjernog sustava

Pressure/flow curves obtained as a result of the characterization of capillary tubes in the hydraulic conductance test setup were used to measure the hydraulic

Table 1 Measurement results of calibration of capillary tubes Tablica 1. Mjerni rezultati kalibriranja kapilara

\begin{tabular}{|c|c|c|c|c|c|c|}
\hline $\begin{array}{l}\text { Capillary } \\
\text { tube } \\
\text { Kapilara } \\
\end{array}$ & \multicolumn{2}{|c|}{$\begin{array}{c}\text { Inlet set pressure, kPa } \\
\text { Tlak na ulazu, } \mathrm{kPa}\end{array}$} & \multirow{2}{*}{$\begin{array}{c}\begin{array}{c}\text { Average pressure } \\
\text { difference, } \mathbf{k P a}\end{array} \\
\text { Prosječna razlika tlaka, } \mathrm{kPa} \\
56\end{array}$} & \multirow{2}{*}{$\begin{array}{l}\text { Liquid quantity, ml } \\
\text { Količina tekućine, ml } \\
20\end{array}$} & \multirow{2}{*}{$\begin{array}{c}\text { Time, s } \\
\text { Vrijeme, s } \\
881\end{array}$} & \multirow{2}{*}{$\begin{array}{c}\text { Flow, } \mathbf{~ m l} / \mathbf{s} \\
\text { Protok, } \mathrm{ml} / \mathrm{s}\end{array}$} \\
\hline \multirow{10}{*}{1} & 50 & 55 & & & & \\
\hline & 55 & 60 & 60 & 12 & 491 & 0.0244 \\
\hline & 60 & 65 & 64 & 12 & 479 & 0.0250 \\
\hline & 65 & 70 & 70 & 10 & 375 & 0.0266 \\
\hline & 70 & 75 & 74 & 10 & 350 & 0.0285 \\
\hline & 75 & 80 & 79 & 10 & 354 & 0.0282 \\
\hline & 80 & 85 & 84 & 12 & 414 & 0.0289 \\
\hline & 85 & 90 & 89 & 10 & 350 & 0.0285 \\
\hline & 90 & 95 & 94 & 10 & 353 & 0.0283 \\
\hline & 95 & 100 & 99 & 20 & 648 & 0.0308 \\
\hline \multirow{10}{*}{2} & 50 & 55 & 56 & 4 & 550 & 0.0072 \\
\hline & 55 & 60 & 61 & 4 & 491 & 0.0081 \\
\hline & 60 & 65 & 66 & 6 & 846 & 0.0070 \\
\hline & 65 & 70 & 71 & 10 & 1226 & 0.0081 \\
\hline & 70 & 75 & 76 & 10 & 1223 & 0.0081 \\
\hline & 75 & 80 & 82 & 8 & 819 & 0.0097 \\
\hline & 80 & 85 & 87 & 8 & 894 & 0.0089 \\
\hline & 85 & 90 & 91 & 8 & 745 & 0.0107 \\
\hline & 90 & 95 & 97 & 4 & 425 & 0.0094 \\
\hline & 95 & 100 & 103 & 8 & 730 & 0.0109 \\
\hline \multirow{10}{*}{3} & 50 & 55 & 55 & 6 & 2454 & 0.0024 \\
\hline & 55 & 60 & 60 & 6 & 2177 & 0.0027 \\
\hline & 60 & 65 & 65 & 6.5 & 2265 & 0.0028 \\
\hline & 65 & 70 & 71 & 6.5 & 2261 & 0.0028 \\
\hline & 70 & 75 & 76 & 6 & 2007 & 0.0029 \\
\hline & 75 & 80 & 81 & 6 & 2081 & 0.0028 \\
\hline & 80 & 85 & 86 & 6 & 1934 & 0.0031 \\
\hline & 85 & 90 & 89 & 6 & 1722 & 0.0034 \\
\hline & 90 & 95 & 96 & 6.5 & 1778 & 0.0036 \\
\hline & 95 & 100 & 101 & 5.5 & 1272 & 0.0043 \\
\hline
\end{tabular}


conductance of the wood samples. To get reliable and comparable results three different capillary tubes were characterized.

In the characterization process, due to very thin diameters of the capillary tubes, different pressures from 50 to $100 \mathrm{kPa}(0.50$ to $1 \mathrm{bar})$ were applied. A relationship was determined over the flow rates corresponding to the different pressures. Accordingly, it has been found that flow rate increases with the increase of inlet pressure. A similar pressure difference-flow relationship was revealed by Cochard (2002). The pressure setpoints, average differential pressures and flow rates used during the characterization process are given in Table 1.

In order to make precise measurements, all processes were applied very carefully, which directly relates to accurate readings of the liquid quantities, accurate determination of the duration and accuracy of the sensor during the characterization process. A long duration test was planned, so the right measurements could be taken in stable conditions.

The three different capillary pipes used in the system have resulted in three different flow values against the different pressures applied. The resulting pressure/flow linear approximation curves and equations are shown in Figure 5.

In order to find the pressure difference caused by the internal resistances of the system, the pressure difference was determined as $1 \mathrm{kPa}(0.01 \mathrm{bar})$ during the system calibration. The obtained value was considered in the pressure difference measured during the hydraulic conductance measurement.

The test setup is based on the same principle as established by Tyree et al. (2002). Besides the similarity in the test method, the proposed test setup was chosen to be suitable for the determination of hydraulic conductance values along the stem of Uludağ Fir. The main difference is the selection of the liquid pump and vacuum pump to give the desired pressures. In addition, their ability to be controlled via the computer and stabilizing the pump pressures by using feedback from the sensor data, are the outstanding features of the test setup. Another important feature of the system is that there is no need for additional test equipment required for calibration or preparation for the test (e.g. pressurized water). Thanks to the features of the system, such as keeping log records of sensor data, instant control of data and determination of stable measuring ranges, measurement faults or operator-induced measurement errors are prevented. In this way, a more systematic method was introduced.

\subsection{Hydraulic conductance results}

3.2. Rezultati hidrauličke vodljivosti

Nine measurements were made on the samples taken from Uludağ Fir (Abies bornmulleriana Mattf.) in the longitudinal direction, with three different capillary tubes and three times of replication of the test. The radial conduction during the measurements was ignored. Table 2 shows the measurement results.

When calculating hydraulic conductance, the "average pressure differences" corresponding to the pressure set values of $85-90 \mathrm{kPa}(0.85-0.90$ bar) were

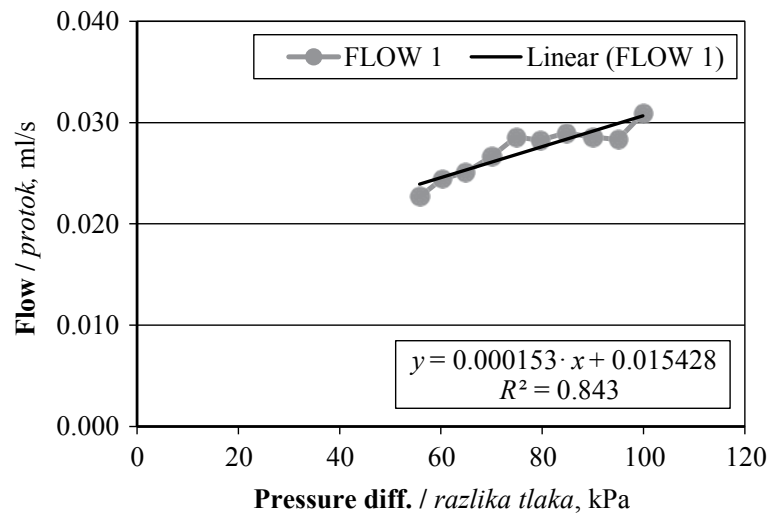

(a)

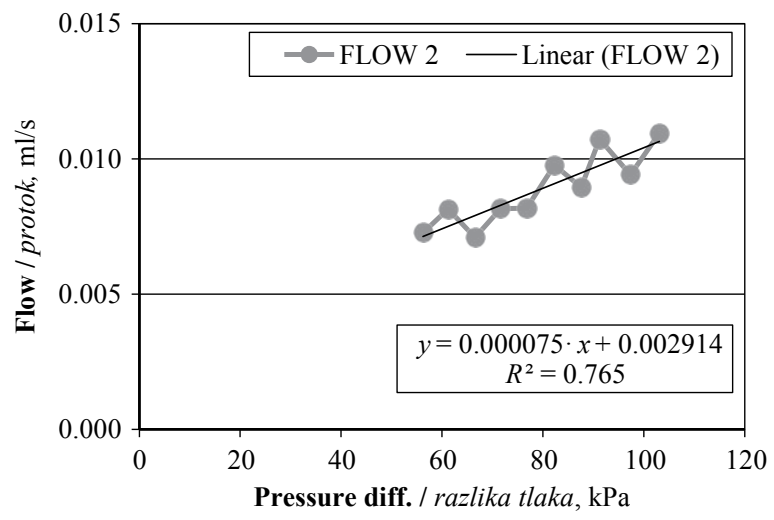

(b)

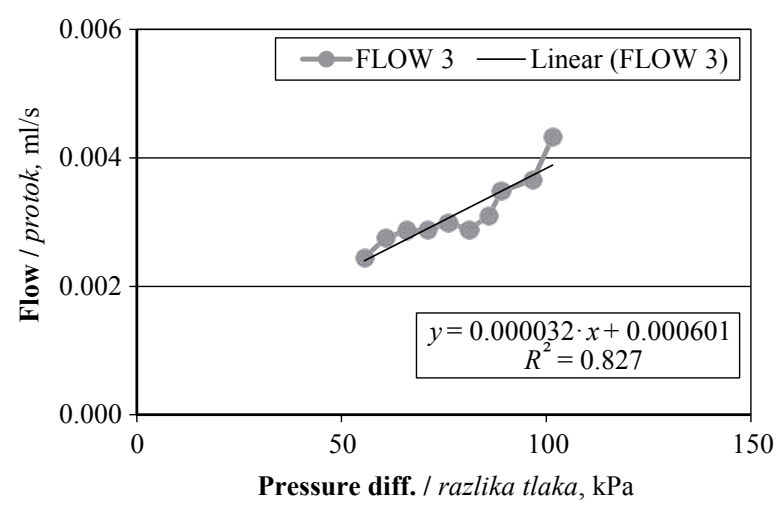

(c)

Figure 5 a) Capillary Tube 1 pressure/flow linear approximation curve and equation, b) Capillary Tube 2 pressure/flow linear approximation curve and equation, c) Capillary Tube 3 pressure/flow linear approximation curve and equation Slika 5. a) Graf i jednadžba linearne aproksimacije ovisnosti tlaka i protoka za kapilaru 1, b) graf i jednadžba linearne aproksimacije ovisnosti tlaka i protoka za kapilaru 2, c) graf i jednadžba linearne aproksimacije ovisnosti tlaka i protoka za kapilaru 3

taken from the system and the pressure difference value $(1 \mathrm{kPa})$ determined during the calibration of the system was added to this value. Accordingly, "calibrated average pressure difference" was found. The "pressure difference of the sample" was obtained by subtracting the vacuum tube pressure from the mean outlet pressure, which is read from the system. Then, using the equations obtained during the characterization of capillary tubes, the "flow" amounts corresponding to the 
Table 2 Hydraulic conductance value of Uludağ Fir (Abies bornmulleriana Mattf.)

Tablica 2. Vrijednosti hidrauličke vodljivosti jelovine (Abies bornmulleriana Mattf.)

\begin{tabular}{|c|c|c|c|c|c|c|c|c|c|}
\hline $\begin{array}{c}\text { Capillary } \\
\text { tube no } \\
\text { Broj } \\
\text { kapilare }\end{array}$ & \multicolumn{2}{|c|}{$\begin{array}{l}\text { Pressure } \\
\text { set value, } \\
\text { kPa } \\
\text { Postavljena } \\
\text { vrijednost } \\
\text { tlaka, } \mathrm{kPa}\end{array}$} & $\begin{array}{c}\text { Measured } \\
\text { average } \\
\text { pressure } \\
\text { diff, kPa } \\
\text { Izmjerena } \\
\text { prosječna } \\
\text { razlika } \\
\text { tlaka, } \mathrm{kPa}\end{array}$ & $\begin{array}{l}\text { Calibrated } \\
\text { average } \\
\text { pressure } \\
\text { diff, kPa } \\
\text { Kalibrirana } \\
\text { prosječna } \\
\text { razlika } \\
\text { tlaka, } \mathrm{kPa}\end{array}$ & $\begin{array}{c}\text { Average } \\
\text { outlet } \\
\text { pressure, } \\
\text { kPa } \\
\text { Prosječni } \\
\text { izlazni } \\
\text { tlak, } \mathrm{kPa}\end{array}$ & $\begin{array}{c}\text { Average } \\
\text { vacuum tube } \\
\text { pressure, } \\
\text { kPa } \\
\text { Prosječni tlak } \\
\text { u vakuumskoj } \\
\text { cijevi, } \mathrm{kPa}\end{array}$ & $\begin{array}{c}\text { Diff. } \\
\text { pressure } \\
\text { on sample, } \\
\mathbf{k P a} \\
\text { Razlika } \\
\text { tlaka } u \\
\text { uzorku, } \\
\mathrm{kPa}\end{array}$ & $\begin{array}{l}\text { Calculated } \\
\text { flow, } \mathbf{~ m l} / \mathbf{s} \\
\text { Izračunani } \\
\text { protok, } \mathrm{ml} / \mathrm{s}\end{array}$ & $\begin{array}{c}\text { Hydraulic } \\
\text { conductance, } \\
\mathbf{m l} \cdot \mathbf{s}^{-1} \cdot \mathbf{M P a}^{-1} \\
\cdot \mathbf{1 0}^{-2} \\
\text { Hidraulička } \\
\text { vodljivost, } \\
\mathrm{ml} \cdot \mathrm{s}^{-1} \cdot \mathrm{MPa}^{-1} \\
\cdot 10^{-2}\end{array}$ \\
\hline 1 & $\begin{array}{l}85 \\
85 \\
85\end{array}$ & $\begin{array}{l}90 \\
90 \\
90\end{array}$ & $\begin{array}{c}2.9 \\
5.2 \\
12.1\end{array}$ & $\begin{array}{c}3.9 \\
6.2 \\
13.1\end{array}$ & $\begin{array}{l}86.3 \\
82.7 \\
76.1\end{array}$ & $\begin{array}{l}50.5 \\
49.6 \\
50.8\end{array}$ & $\begin{array}{l}35.8 \\
33.1 \\
25.3\end{array}$ & $\begin{array}{l}0.0021 \\
0.0024 \\
0.0014\end{array}$ & $\begin{array}{l}5.8 \\
7.3 \\
5.5\end{array}$ \\
\hline 2 & $\begin{array}{l}85 \\
85 \\
85\end{array}$ & $\begin{array}{l}90 \\
90 \\
90\end{array}$ & $\begin{array}{l}1.8 \\
3.3 \\
9.9\end{array}$ & $\begin{array}{c}2.8 \\
4.3 \\
10.9\end{array}$ & $\begin{array}{l}86.1 \\
83.8 \\
76.9\end{array}$ & $\begin{array}{l}51.1 \\
51.2 \\
51.6\end{array}$ & $\begin{array}{l}35.0 \\
32.7 \\
25.3\end{array}$ & $\begin{array}{l}0.0019 \\
0.0023 \\
0.0013\end{array}$ & $\begin{array}{l}5.5 \\
7.1 \\
5.2\end{array}$ \\
\hline 3 & $\begin{array}{l}85 \\
85 \\
85\end{array}$ & $\begin{array}{l}90 \\
90 \\
90\end{array}$ & $\begin{array}{c}1.6 \\
3.5 \\
11\end{array}$ & $\begin{array}{c}2.6 \\
4.5 \\
12.0\end{array}$ & $\begin{array}{l}85.6 \\
83.1 \\
75.8\end{array}$ & $\begin{array}{l}51.3 \\
51.5 \\
51.0\end{array}$ & $\begin{array}{l}34.3 \\
31.7 \\
24.9\end{array}$ & $\begin{array}{l}0.0019 \\
0.0023 \\
0.0014\end{array}$ & $\begin{array}{l}5.5 \\
7.3 \\
5.5\end{array}$ \\
\hline
\end{tabular}

Table 3 Mean, minimum and maximum value and standard deviation of hydraulic conductance measurement result Tablica 3. Srednja, najmanja i najveća vrijednost i standardna devijacija izmjerene hidrauličke vodljivosti

\begin{tabular}{|c|c|c|c|c|}
\hline $\boldsymbol{n}$ & $\begin{array}{c}\boldsymbol{x} \\
\mathrm{ml} \cdot \mathrm{s}^{-1} \cdot \mathrm{MPa}^{-1} \cdot 10^{-2}\end{array}$ & $\begin{array}{c}\text { Min. Value } \\
\mathrm{ml} \cdot \mathrm{s}^{-1} \cdot \mathrm{MPa}^{-1} \cdot 10^{-2}\end{array}$ & $\begin{array}{c}\text { Max. Value } \\
\mathrm{ml} \cdot \mathrm{s}^{-1} \cdot \mathrm{MPa}^{-1} \cdot 10^{-2}\end{array}$ & Stand. dev. \\
\hline 9 & 6.1 & 5.2 & 7.4 & 0.9 \\
\hline
\end{tabular}

average pressure differences were found. Finally, the calculated flow rate is divided into the pressure difference $(F / \Delta P)$ to obtain "hydraulic conductance" for each sample. Accordingly, the hydraulic conductance was $6.2 \mathrm{ml} \cdot \mathrm{s}^{-1} \cdot \mathrm{MPa}^{-1} \cdot 10^{-2}$ for Capillary Tube $1,5.9$ $\mathrm{ml} \cdot \mathrm{s}^{-1} \cdot \mathrm{MPa}^{-1} \cdot 10^{-2}$ for Capillary Tube 2 and $6.1 \mathrm{ml} \cdot$ $s^{-1} \cdot \mathrm{MPa}^{-1} \cdot 10^{-2}$ for Capillary Tube 3 . The mean, minimum and maximum values and standard deviation of all measurement results are also shown in Table 3.

\section{CONCLUSIONS AND RECOMMENDATIONS} 4. ZAKLJUČAK I PREPORUKE

In this study, a hydraulic conductance test setup was established to determine the hydraulic conductance, which is one of the important parameters of liq- uid transport system in trees. The hydraulic conductance of the samples taken from fir wood was measured using the proposed test setup. Measurements were carried out with pressurized water. By applying 0-100 kPa pressure on samples placed in a vacuum tube, successful results were obtained.

To conclude, as seen in Figure 3, meaningful trend lines were obtained indicating that the flow increases with the increase in inlet pressure. Hydraulic conductance results of different samples, prepared with the same procedure from the same tree section, show that measurements are consistent with low standard deviation as shown in Figure 6. With the increasing number of tests, statistical analyses can be improved. Also, in future studies, the conductivity values of fir tree samples taken from different regions, different ages,

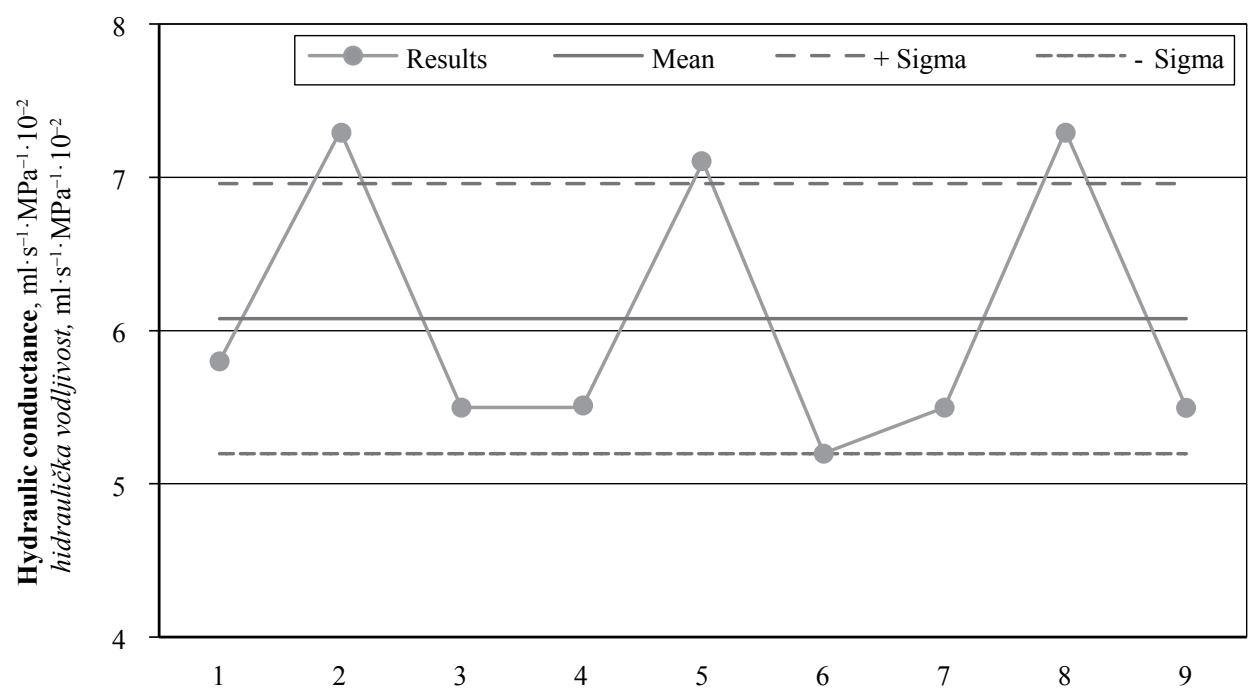

Figure 6 Comparison of results

Slika 6. Usporedba rezultata 
and different seasons can be measured and compared with the values found.

The fact that the curves obtained from three different capillary tubes are linear and consistent and that the measured values taken from the samples are similar to each other can be taken as proof that the system works correctly.

In the scope of our study, samples taken from the stem were used in the test setup. On the other hand, the test setup is also adaptable for samples from roots, shoots and leaves. It is foreseen that this system can be used by researchers in their studies that can be carried out in many fields such as plant physiology, ecology and agriculture.

This study may be used other research related to hydraulic conductance such as different tree and plant species, different tree and plant parts, as well as different soil and water properties. With such future studies, it will be possible to get an idea about the liquid transportation system in trees.

\section{REFERENCES}

5. LITERATURA

1. Christman, M. A.; Sperry, J. S., 2010: Single vessel flow measurements indicate scalariform perforation plates confer higher flow resistance than previously estimated. Plant, Cell and Environment, 33: 431-443. https://doi.org/10.1111/j.1365-3040.2009.02094.x.

2. Cochard, H.; Breda, N.; Granier, A., 1996: Whole tree hydraulic conductance and water loss regulation in Quercus during drought: evidence for stomatal control of embolism? Annales des Sciences Forestieres, 53: 197-206.

3. Cochard, H., 2002: A technique for measuring xylem hydraulic conductance under high negative pressures. Plant, Cell \& Environment, 25: 815-819. https://doi.org/10.1046/j.1365-3040.2002.00863.x.

4. Cruiziat, P.; Cochard, H.; Améglio, T., 2002: Hydraulic architecture of trees: main concepts and results. Annals of Forest Science, 59: 723-752. https://dx.doi.org/10.1051/forest:2002060.

5. Davis, S. D.; Sperry, J. S.; Hacke, U. G., 1999: The relationship between xylem conduit diameter and cavitation caused by freezing. American Journal of Botany, 86: 1367-1372. https://doi.org/10.2307/2656919.

6. Fontes, C. G.; Dawson, T. E.; Jardine, K.; McDowell, N.; Gimenez, B. O.; Anderegg, L.; Negrón-Juárez, R.; Higuchi, N.; Fine, P. V. A.; Araújo, A. C.; Chambers, J. Q., 2018: Dry and hot: the hydraulic consequences of a climate change-type drought for Amazonian trees. Philosophical Transactions of the Royal Society B: Biological Sciences, 373 (1760): 20180209. https://doi.org/10.1098/rstb.2018.0209.

7. Gibson, A. C.; Calkin, H. W.; Nobel, P. S., 1984: Xylem anatomy, water flow, and hydraulic conductance in the fern Cyrtomium falcatum. American Journal of Botany, 71: 564-574. https://doi.org/10.1002/j.1537-2197.1984.tb12542.x.

8. Granier, A.; Breda, N.; Claustres, J. P.; Colin, F., 1989: Variation of hydraulic conductance of some adult conifers under natural conditions. Annales des sciences forestières, EDP Sciences, 46: 357-360.

9. Hubbard, R. M.; Bond, B. J.; Ryan, M. G., 1999: Evidence that hydraulic conductance limits photosynthesis in old Pinus ponderosa trees. Tree Physiology, 19: 165172. https://doi.org/10.1093/treephys/19.3.165.
10. Kolb, K. J.; Sperry, J. S.; Lamont, B. B., 1996: A method for measuring xylem hydraulic conductance and embolism in entire root and shoot systems. Journal of Experimental Botany, 47: 1805-1810. https://doi.org/10.1093/jxb/47.11.1805.

11. Ladjal, M.; Huc, R.; Ducrey, M., 2005: Drought effects on hydraulic conductivity and xylem vulnerability to embolism in diverse species and provenances of Mediterranean cedars. Tree Physiology, 25: 1109-1117. https://doi.org/10.1093/treephys/25.9.1109.

12. Melcher, P. J.; Holbrook, N. M.; Burns, M. J.; Zwieniecki, M. A.; Cobb, A. R.; Brodribb, T. J.; Choat, B.; Sack, L., 2012: Measurements of stem xylem hydraulic conductivity in the laboratory and field. Methods in Ecology and Evolution, 3: 685-694. https://doi.org/10.1111/j.2041-210X.2012.00204.x.

13. Pallardy, G. G., 2008: Physiology of Woody Plants. Academic Press. Inc. San Diego. https://doi.org/10.1016/B978-0-12-424162-6.X5017-0.

14. Pereira, L.; Mazzafera, P., 2012: A low cost apparatus for measuring of xylem hydraulic conductance in plants. Bragantia, 71: 583-587. http://dx.doi.org/10.1590/S0006-87052013005000006.

15. Sperry, J. S.; Donnelly, J. R.; Tyree, M. T., 1988: A method for measuring hydraulic conductivity and embolism in xylem. Plant Cell and Environment, 11: 35-40. https://doi.org/10.1111/j.1365-3040.1988.tb01774.x.

16. Sperry, J. S.; Hacke, U. G.; Wheeler, J. K., 2005: Comparative analysis of end wall resistivity in xylem conduits. Plant, Cell and Environment, 28: 456-465. https://doi.org/10.1111/j.1365-3040.2005.01287.x.

17. Sperry, J. S.; Love, D. M., 2015: What plant hydraulics can tell us about responses to climate change droughts. New Phytologist, 207: 14-27. https://doi.org/10.1111/nph.13354.

18. Torres-Ruiz, J. M.; Sperry, J. S.; Fernández, J. E., 2012: Improving xylem hydraulic conductivity measurements by correcting the error caused by passive water uptake. Physiol Plant, 146: 129-135. https://doi.org/10.1111/j.1399-3054.2012.01619.x.

19. Tyree, M. T.; Ewers, F. W., 1991: The hydraulic architecture of trees and other woody plants. New Phytologist, 119: 345360. https://doi.org/10.1111/j.1469-8137.1991.tb00035.x.

20. Tyree, M. T.; Patiño, S.; Bennink, J.; Alexander, J., 1995: Dynamic measurements of root hydraulic conductance using a high-pressure flowmeter in the laboratory and field. Journal of Experimental Botany, 46: 83-94. https://doi.org/10.1093/jxb/46.1.83.

21. Tyree, M. T.; Vargas, G.; Engelbrecht, B. M. J.; Kursar, T. A., 2002: Drought until death do us part: a case study of the desiccation-tolerance of a tropical moist forest seedling-tree, Licania platypus (Hemsl.) Fritsch. Journal of Experimental Botany, 53: 2239-2247. https://doi.org/10.1093/jxb/erf078.

22. Tyree, M. T.; Zimmermann, M. H., 2002: Xylem Structure and the Ascent of Sap, $2^{\text {nd }}$ ed. Springer-Verlag, Berlin. https://doi.org/10.1007/978-3-662-04931-0.

23. Zwieniecki, M. A.; Melcher, P. J.; Holbrook, N. M., 2001: Hydraulic properties of individual xylem vessels of Fraxinus americana. Journal of Experimental Botany, 52: 257-264. https://doi.org/10.1093/jxb/52.355.257.

\section{Corresponding address:}

\section{SUHEYLA ESIN KOKSAL}

Bolu Abant Izzet Baysal University

Mudurnu Sureyya Astarci Vocational School

Department of Forestry

14800, Bolu, TURKEY

e-mail: esinkoksal@ibu.edu.tr 